\title{
Hydrogeochemical Conditions of the Development of Anthropogenic Carbonate Swamps: A Case Study of an Abandoned Polish Sandpit
}

\author{
Agnieszka Błońska1, Joanna Kidawa², Tadeusz Molenda², Damian Chmura ${ }^{3 *}$ \\ ${ }^{1}$ Department of Geobotany and Nature Protection, University of Silesia, Katowice, Poland \\ ${ }^{2}$ Department of Physical Geography, University of Silesia, Sosnowiec, Poland \\ ${ }^{3}$ Institute of Environmental Protection and Engineering, University of Bielsko-Biala, Bielsko-Biała, Poland
}

Received: 13 December 2018

Accepted: 29 January 2019

\begin{abstract}
The hydrogeochemical conditions of the development of a carbonate swamp that had formed in a previous sandpit were studied. The object is located in the town of Jaworzno-Szczakowa in the Silesian Upland of southern Poland. It has been shown that the sandpit, which has not been reclaimed since its operation ceased, underwent spontaneous processes toward the development of calciphilic vegetation. The Biała Przemsza River plays a significant role in supplying the swamp with water. The water of this river is highly contaminated because it receives wastewaters from zinc-lead $(\mathrm{Zn}-\mathrm{Pb})$ ore mines. Water that has high concentrations of calcium and magnesium ions favours the occurrence of calciphilic species (e.g., Liparis loeselii NATURA 2000 species), which form wetlands of carbonate vegetation that are rare in both Poland and Europe. The population size of this species on the studied swamp is a few hundred specimens. In addition to Liparis loeselii, there are other species that are protected or rare and endangered species at the national level and on the "red list" of Poland's plants, hence such swamps could represent an important refuge for biodiversity.
\end{abstract}

Keywords: human-made wetlands, mining water, opencast, water pollution, vascular flora

\section{Introduction}

Non-reclaimed sandpits are spontaneously colonised by plants [1-5]. The colonisation of these areas by plants depends primarily on local habitat factors such as light, the granulometric composition of the soil, $\mathrm{pH}$, soil

*e-mail: dchmura@ath.bielsko.pl fertility, moisture, etc. [6-7]. Disused sandpits are mostly spontaneously entered by xerophytic andoligotrophic species, mainly from psammophilous grasslands and ruderal habitats [1-3], thereby creating species-poor phytocoenoses.

Much less frequently, the development of wetlands occurs at the bottom of the excavation at the groundwater outflow [8-10]. Objects of this type were found within a few non-recultivated sand or gravel pits, mainly in 
Poland. At these damp sites at the base of the excavation of sand or gravel pits that have been saturated with groundwater, valuable plant species occur, particularly species that are characteristic of low carbonate bogs. To date, the specialist literature has primarily emphasised the importance of such swamps for the preservation of biological diversity, thus indicating the existence of valuable plant species, particularly those that are characteristic of low carbonate bogs, and in terms of phytosociological units, those of the Caricetalia davallianae order [5, 10-15]. However, there is no data on the hydrogeochemical conditions of this type of anthropogenic swamp with bog vegetation, which are valuable from the point of view of nature conservation.

The aim of our study was to demonstrate that water that has been contaminated by the discharge of mine water could be responsible for the development of swamps and thus the direction of vegetation succession in sandpits.

\section{Material and Methods}

\section{Description of the Study Area}

Our study was conducted in the Szczakowa sandpit, which is located in the Silesian a macro region and that coversan area of ca. $4000 \mathrm{~km}^{2}$. The mean annual temperature in the Silesian Upland is about $7-8^{\circ} \mathrm{C}$ and the annual precipitation in the area ranges from 700 to $800 \mathrm{~mm} /$ year and snow retention is approx. 5070 days. In the Silesian Upland, peat bog ecosystems are very rare, but the occurrence of wetland species of the Scheuchzerio-Caricetea nigrae class and combinations of the species that are typical of bogs are observed in the anthropogenic areas. Most of these are disused sandpits, gravel pits, railway areas and the edges of anthropogenic water reservoirs, etc. [15-16].

The swamp that was selected for the study developed at the base of an old sandpit after its operation ceased in the 1970s [personal communication from the employers
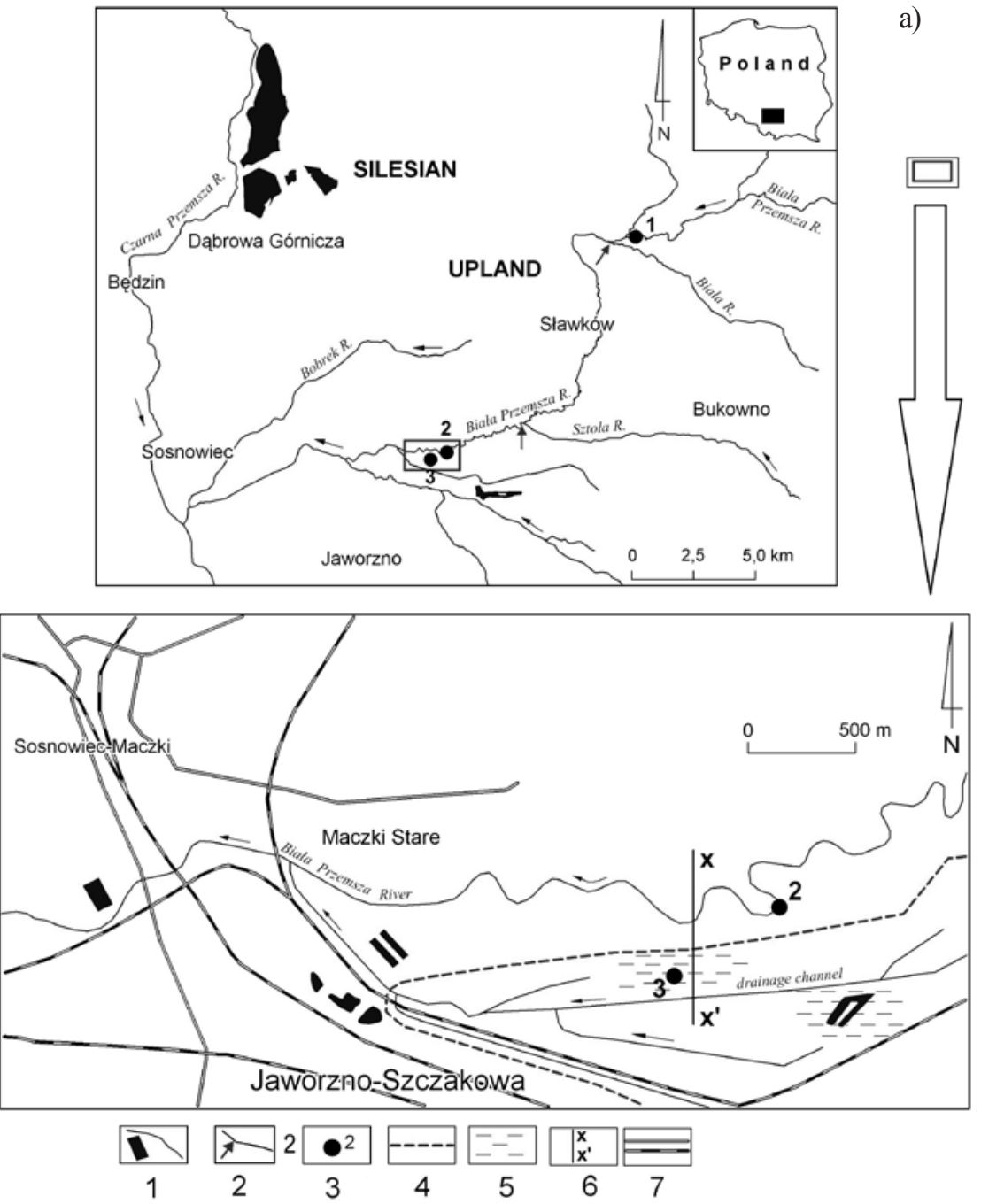

b)

Fig. 1. Location of the study area a) and study design b): 1 - rivers and reservoirs, 2 - mine water discharge into the Biała Przemsza River, 3 - sites of the water sampling for the chemical analyses, 4 - the border of the sand pit excavation, 5 - anthropogenic swamp, 6 hydrogeological cross-section, 7 - roads and railway lines. 
of the Jaworzno Sand Mine]. It is situated in Jaworzno $\left(50^{\circ} 15^{\prime} 11.92^{\prime \prime} \mathrm{N}\right.$; $\left.19^{\circ} 18^{\prime} 21.45^{\prime \prime} \mathrm{E}\right)$ in the Silesian Upland (Fig. 1) in the valley of the Biała Przemsza River, which is the left tributary of the Vistula River. The area of the wetland that was analysed is ca. 6 ha. This river feeds the swamp that was analysed. The river receives the mining water from the drainage of the zinc and lead ore mines that are located in the upper part of the catchment. In addition, the Biała Przemsza River receives water from the processing of zinc and lead ores and wastewater from the zinc smelter. The peat bog that is fed by the waters of this river is located downstream of the discharge of these pollutants. About 700 million $\mathrm{m}^{3}$ of sand was excavated for the coal mining (backfilling material). In the initial period of the extraction of the deposit, when the raw materials were located above the groundwater table, the pit was only fed by rainwater and the water from the surface runoff [17]. Once the bottom of the exploitation pit fell below the groundwater table, this water flowed out from the excavation. The dewatering of the excavation occurred either by gravity through a network of ditches and canals or through pumping systems.

After the operation ceased, the pumping was discontinued and water flooded the pit, which in turn led to the creation of an excavation reservoir. When the gravity drainage was in operation, the network of ditches and canals continued to fulfil these functions and the excavation remained dry. In many cases, however, there were cavities within the large pit that were difficult to dewater by gravity. Then the bottom of such hollows was constantly dumped and was even flooded (Fig. 2).

\section{Methods}

\section{Hydrological Research}

Hydrographic mapping to assess the water conditions in the Szczakowa swamp area was concordant with the guidelines provided by Gutry-Korycka and WernerWięckowska [18].

The location of the sampling points for the physicochemical analyses of the water arepresented in Fig. 1. Water samples were collected from both the swamp (sampling point 3) and the Biała Przemsza River (sampling points 1 and 2). The selection of the sampling points on the Biała Przemsza River (1 and 2) was dictated by the need to demonstrate how the mine water discharge affected the quality of the river water. Sampling point 1 is located above the mine water discharge and sampling point 2 below the mine water discharge (Fig. 1).

At every sampling point, a water sample was collected at monthly intervals (from November 2012 through October 2013; $\mathrm{n}=12$ ). The field measurements and samplings were performed in the water pools that were stagnating on the swamp surface. No water was squeezed from the organic deposits. River water was collected in the current using a telescopic boom. Water samples were collected in 0.51 polyethylene bottles. The water samples were transported to the laboratory at a temperature of $+4^{\circ} \mathrm{C}$. Before the analyses, the samples were filtered on a $0.45 \mu \mathrm{m}$ filter (Millipore). Laboratory analyses included determining the major cations and anions, $\mathrm{Ca}^{2+}, \mathrm{Mg}^{2+}$ and $\mathrm{SO}_{4}^{2-}$, in the water. These are typical indicators of mine waters [19]. The analyses
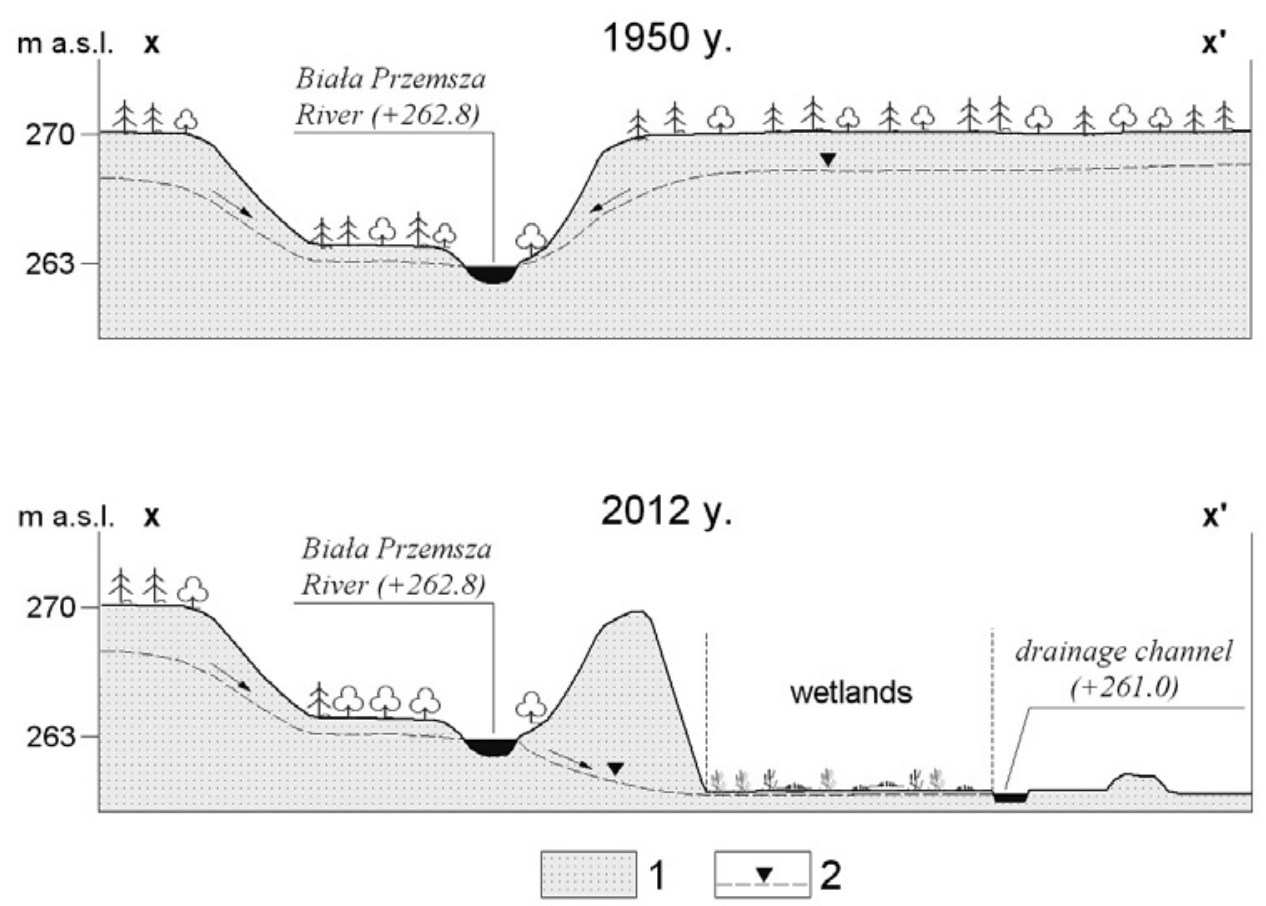

Fig. 2. Hydrogeological cross-section of Szczakowa swamp: 1-sands, 2 - water table. 
were performed on a Metrohm 850 Professional IC ion chromatograph. Measurements of $\mathrm{pH}$ and electro-conductivity (EC) were performed directly in the field using a professional plus meter by the YSI Company.

Because precipitated evaporites were observed on the swamp surface(supplementary material, Fig. S1), it was decided to determine the type of minerals that were involved. In order to identify the minerals (evaporates) that had precipitated on the surface of the swamp; plants that had encrustings of the minerals were collected. The encrustings were prepared for environmental scanning (SEM) and the test was performed on a Philips XL 30 ESEM / TMP scanning electron microscope with an EDS analysis appliance (EDAX Sapphire type). BSE (back-scattered electron) photographs were taken in the micro areas of the tested preparations. The elemental composition and presumptive identification of minerals was based on ananalys is of the EDS spectra (scanning dispersive electron microscopy).

\section{Floristic Studies}

In order to catalogue the spontaneous flora during the growing season (June-August), a full floristic inventory of the vascular plants of the entire swamp was performed in 2013 (Table S1). The collected floristic data were analysed in terms of the ecological requirements using the Ellenbergindicator values for plant species (EIVs, [20]) in order to show the site characteristics for light $(\mathrm{L})$, moisture $(\mathrm{F})$, reaction $(\mathrm{R})$ and nitrogen (fertility, N). Arithmetic means based on the presence/absence of the EIVs and the distribution of the plants that represented specific values of the EIVsare shown. For the calculations, the species waassigned an "X", i.e., without any diagnostic value being excluded from the calculations. In addition, a soil $\mathrm{pH}$-meter was used to determine the soil reaction in the rhizosphere of the majority of the plants, i.e., 3-4 cm in the top layer of the soil and below $10 \mathrm{~cm}$. Ten measurements were performed in randomly selected sites within the swamp. The participation of species of different syntaxonomic groups in the flora of the object with particular emphasis on peat bog species was performed. The syntaxonomic classification of the species was based on the Polish guide to plant determination [21]. To determine the role of the wetlands as biodiversity refuges, plants that are protected in Poland [22] and those that are deemed endangered in the country as well as those that are of European importance were also considered [23]. The nomenclature of the vascular plants was adopted after [24].

\section{Data Analysis}

To test the significance of differences between the concentrations of the analysed ions, the nonpar a metric equivalent of ANOVA, the Kruskal-Wallis test was used, while for multiple comparisons we used the Conover test. Statistical analyses were performed using R software (www.r-project.org) and the stats and agricolae packages.

\section{Results and Discussion}

\section{Results \\ Hydrochemical Conditions of the Szczakowa Swamp Development}

The values of all of the tested water parameters were significantly higher at sampling point 2 compared to sampling point 1 . The average value of the electrolytic conductivity of the Szczakowa wetland water was the highest, but was only significantly higher than the one at sampling point 1 (Table 1). In turn, in the case of the concentration of the calcium ions and magnesium ions, significantly higher values were recorded in the swamp (sampling point 3), whereas the highest concentration of sulfates was noted at sampling point 2. The higher average concentration of calcium in relation to the water supply was connected with the evaporation processes. When evaporation is complete, the evaporites precipitate. These were identified on the SEM figures (Fig. S1). In the wetland, two zones of mineral formations could be distinguished: an aerated zone and a permanently water-saturated zone (Fig. 4). In the aerated zone, the mineral evaporites such as calcium carbonate $\left(\mathrm{CaCO}_{3}\right)$ and gypsum $\left(\mathrm{CaSO}_{4} * 2 \mathrm{H}_{2} \mathrm{O}\right)$ were formed. This zone was characterized by an alkaline $\mathrm{pH}$, i.e., 7.5-8.0, which classifies the object as an anthropogenic carbonate wetland. In the water-saturated zone, there were reduced conditions that favoured the formation of pyrites $\left(\mathrm{FeS}_{2}\right)$. This was an acidic zone in which $\mathrm{pH}$ varied between 4.0 and 5.0 .

\section{Flora that were Spontaneously Colonising the Swamp}

At the Szczakowa swamp, 91 species of vascular plants were recorded (Table S1). Because the analysed swamp is of an initial character, a small proportion of trees and shrubs was also observed (mainly light-seed species such as Alnus glutinosa, A. incana, Betula pubescens, Pinus sylvestris) and thus, there was slight shading. Therefore, species of open habitats were predominant (the average value of the light coefficient based on the Ellenberg indicator value was 7.14) (Fig. 3L). Due to the high degree of the dampness of the substrate, the dominant species represented those of damp and wet habitats and the average moisture ratio (F, EIV for moisture) was 7.4. (Fig. 3F). High concentrations of calcium and magnesium ions in the water that supplied the swamp and that affected the $\mathrm{pH}$ were responsible for the presence of alkaliphilic species (Fig. 3R). The average R, EIV for the soil reaction was 6.3 and the calciphytes were dominated 
Table 1. Medians \pm interquartile range of the physical-chemical parameters of the objects; different letters indicate that the values are significantly different at $\mathrm{p}<0.05$ (Kruskal-Wallis test followed by Conover test as post-hoc).

\begin{tabular}{|c|c|c|c|c|c|}
\hline Sampling points & $\# 1$ & $\# 2$ & $\# 3$ & chi-square & $\mathrm{p}$ \\
\hline Conductivity & b $400 \pm 8.5$ & a $816 \pm 36$ & a $1013 \pm 378.3$ & 14.83 & $<0.001$ \\
\hline pH & b $6.6 \pm 0.449$ & a $8.1 \pm 0.1$ & a $7 \pm 0.4$ & 12.76 & $<0.0001$ \\
\hline Calcium ions & c $78 \pm 1.75$ & b $111 \pm 8.8$ & a $153.5 \pm 27.7$ & 19.91 & $<0.001$ \\
\hline Magnesium ions & c $2.1 \pm 2.625$ & b $32 \pm 3.0$ & a $40.5 \pm 6.0$ & 14.44 & $<0.001$ \\
\hline Sulfates & b $43.5 \pm 2.7$ & a $168.7 \pm 32.7$ & a $103.7 \pm 143.4$ & 13.38 & $<0.01$ \\
\hline
\end{tabular}

Explanations: Sampling point 1 is located above the mine water discharge, sampling point 2 - below the mine water dischargeand sampling point 3 - at the swamp

by the species that are typical of alkaline bog-springs, namely Caricion davallianae. However, there were no species that are associated with acidophilus bogs. Below $10 \mathrm{~cm}$ of the top soil layer, the median $\mathrm{pH}$ was 4.38 (4.0-5.0) and in the rhizosphere layer it was 7.65 (7.08.0) (Fig. 4). The species that have low requirements for the soil trophy (N, EIV for nitrogen is 3.7) were dominant (Fig. 3N). An important role in the floristic composition of Szczakowa swamp was played by meadow species and especially the species of wet meadows of the Molinietalia order. The swamp species of the Scheuchzerio-Cariceteanigrae class constituted $18 \%$ of the flora, of which more than half were species that are typical of the calciphylous bog-springs sedges of the Caricetalia davallianae order (Fig. 3). They included Carexdavalliana, C. dioica, C. flava, Eleocharis quinqueflora, Epipactis palustris, Eriophorum latifolium, Parnassia palustris, Tofieldia calyculata and Liparis loeselii. The population of the latter species was estimated to be one hundred individuals on the studied swamp. There were 12 protected species and eight "red list" species, including L. loeselii (Table 2). The plant community on the swamp were typical of the alkaline fens of the community of Caricion davallianae alliance, according to the NATURA 2000 habitat code 7230 .

\section{Discussion of Results}

The sand open pit extraction in the study area has led to significant changes in the relief and water conditions. Such changes have been observed in all of the areas in which there was open cast mining of mineral resources [25, 15]. Particularly significant changes in the water conditions occurred within the tested pit. They consisted of the escape (infiltration) of water from the Biała Przemsza River into the workings of the sandpit. The water of the Biała Przemsza River had a high level of contamination, which was a result of the mine water discharge [26]. Increased values of all the tested parameters of water in the Biała Przemsza River downstream of the concentrated water discharge indicated that the mine water carried a load of ions, which also affected the properties of the water that directly supplied the swamp. This mainly referred to the calcium and magnesium ions as well as sulfates. These, in turn, affected the electrolytic conductivity. The concentration of these ions was greater than that commonly found in the surface water and groundwater in the area [27]. The large participation of calcium and magnesium ions in the contaminants resulted from the fact that $\mathrm{Zn}-\mathrm{Pb}$ ores are found in the dolomite rocks. The higher concentration of calcium ions in the water of the swamp in relation to the water of the Biała Przemsza River, which supplies the swamp, can be explained by the process of water evaporation from the swamp surface.

In the case of Szczakowa swamp, the mean concentration of calcium ions was greater than in the water of the Biała Przemsza River. This phenomenon is explained by the evaporation processes that occurred in the water pools on the surface of the swamp and the increased salinity. In the swamp area, the following evaporites were identified: calcium carbonate $\left(\mathrm{CaCO}_{3}\right)$ and gypsum $\left(\mathrm{CaSO}_{4} * 2 \mathrm{H}_{2} \mathrm{O}\right)$. The high concentrations of sulfates in the mine waters were the result of the weathering of sulphide ore minerals [28]. The precipitation of evaporites was also described by [29], who studied other hydrographic objects of an anthropogenic origin.

Water that is rich in calcium and magnesium ions, in this case of an anthropogenic origin, provides favourable conditions for colonisation by calciphilic plants and, over time, vegetation patches that are similar to the floristic composition of alkaline Caricion davallianae bog-springs are created. Under natural conditions, this type of vegetation occurs at bog-springs, the water of which infiltrates through limestone and forms a habitat that is rich in minerals, including calcium carbonate [21]. Such vegetation occurs on fens. These are very rare habitats that are the refuge of many rare and endangered plant species, which are often of a narrow ecological scale.

The formation of this type of vegetation in disused and non-reclaimed sandpits is unique. In most cases, the uncovered sands of disused sandpits are colonised by psammophilous grasslands, arid grasslands, ruderal species, trees and shrubs. Wetter areas become over grown with rushes such as the common reed (Phragmites 

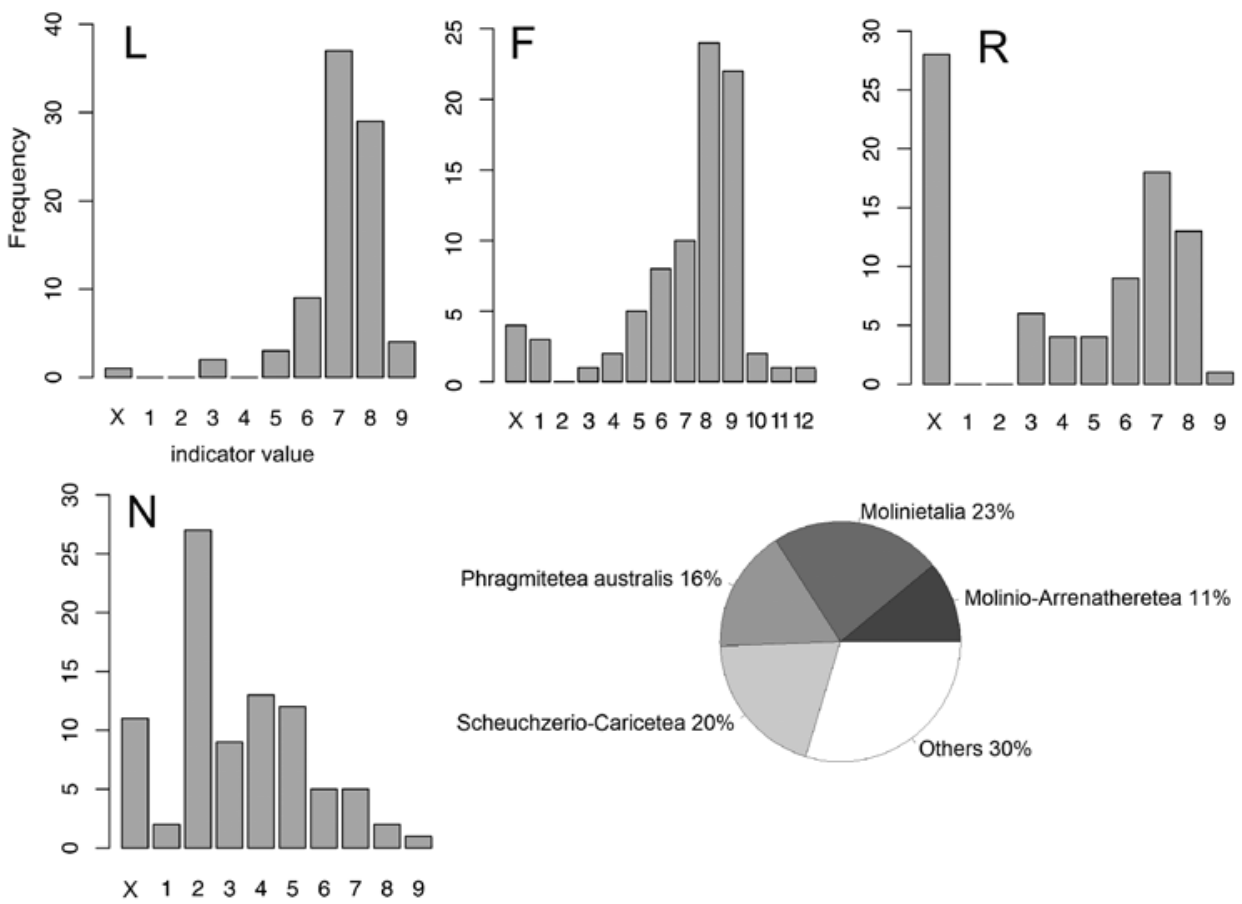

Fig. 3. Distribution of the species that represent specific Ellenberg indicator values (EIVs): L - light, $\mathrm{T}$ - temperature, $\mathrm{F}-$ moisture, $\mathrm{R}$ - soil reaction, $\mathrm{N}$ - nitrogen and percent participation of species to syntaxonomic groups. Explanations: 1-12 values of EIVs, $\mathrm{x}-\mathrm{no}$ specified value.

australis) and broad leaf cattail (Typhalatifolia) $[1,2$, 30].

Bog-springs with calciphilic species have only been reported in southern $[5,12,14]$ and northeastern Poland [13]. Their importance for the conservation of the biodiversity of the region and the country is significant because of the participation of species that are deemed to be endangered in the country as well as the abundance of Liparis loeselii - a species that is of European importance [23], especially because the natural swamp communities in the Silesian Upland are very rare and endangered vegetation components. The particular importance of $\mathrm{Ca}^{2+}$ and $\mathrm{pH}$ is highlighted for the communities of alkaline swamps [31]. Communities that include Liparis loeselii and other calciphilic species that have been found by the Rospuda River grow on a substrate where the water has the following parameters: $\mathrm{pH}-7.0$, conductivity $-466(\max 694), \mathrm{Mg}^{+2}-15.9$, $\mathrm{Ca}^{+2}-21.7$ [32]. In comparison, the concentration of calcium and magnesium ions in the Szczakowa swamp was indeed much higher; nevertheless, they are not toxic to the plant. It is interesting that both magnesium and calcium ions increased in the swamp that was studied because in other anthropogenic habitats (managed forest, agriculture, pastures) there is a negative correlation between the calcium and magnesium ions in soils [33]. The relationship that was observed between the soil $\mathrm{pH}$ and moisture and a spectrum of environmental requirements (expressed by Ellenberg indicator values) of the plants colonising the swamp confirms the view that the patterns of species distribution are a response to the habitat conditions/gradients [34]. The strong degree of dampness of the substratum in Szczakowa swamp is an environmental filter that limits the encroachment of ruderal plants both native expansive and invasive alien

Table 2. Protected and threatened vascular plant species of the analysed swamp in Poland.

\begin{tabular}{|c|c|c|}
\hline Species & $\begin{array}{c}\text { Protected } \\
\text { species in } \\
\text { Poland [27] }\end{array}$ & $\begin{array}{c}\text { Threatened } \\
\text { species in } \\
\text { Poland [28] }\end{array}$ \\
\hline Carex davalliana & $\S \S$ & VU \\
\hline Carex dioica & $\S$ & VU \\
\hline Dactylorhiza incarnata & $\S$ & NT \\
\hline Dactylorhiza majalis & $\S$ & NT \\
\hline Epipactis palustris & $\S \S$ & NT \\
\hline Gentiana pneumonanthe & $\S \S$ & VU \\
\hline Gymnadenia conopsea & $\S \S$ & NT \\
\hline Liparis loeselii & $\S \S$ & VU \\
\hline Malaxis monophyllos & $\S \S$ & VU \\
\hline Pedicularis palustris & $\S$ & VU \\
\hline Tofieldia calyculata & $\S \S$ & NT \\
\hline Utricularia minor & $\S \S$ & NT \\
\hline
\end{tabular}

Categories of protection: $\S \S-$ strict protection, $\S-$ partial protection, Categories of threat: VU - vulnerable, [NT] - near threat. 


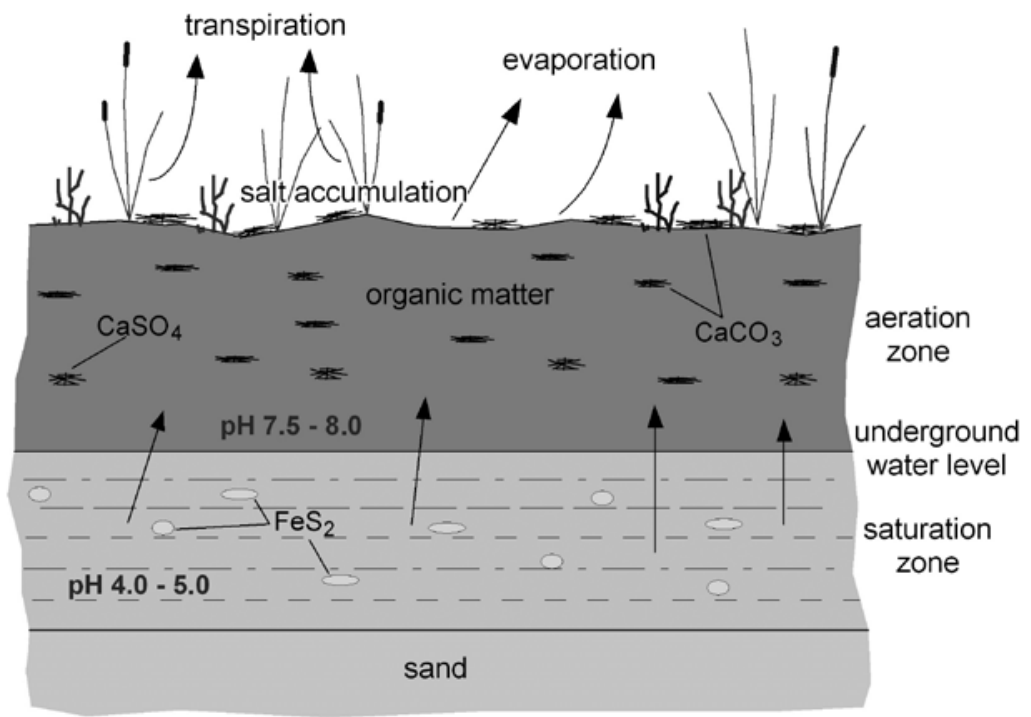

Fig. 4. Process of formation of the evaporites at Szczakowa swamp.

species that threaten the biodiversity of bog-springs, as well as woody plants (shrubs and trees). Thus, if the water conditions are stable, the site will not be overgrown by woody vegetation and will therefore not develop into thickets and forest.

\section{Conclusions}

The relatively high moisture of the habitat and the high concentration of calcium and magnesium ions in Szczakowa swamp are the most likely factors that enhance the encroachment of calciphilic species, including protected and rare species. Maintaining the relevant water conditions is essential for the protection of the site. The study demonstrated that, in some cases, human-induced changes result in the formation of habitats that are refuges for plants that are valuable from a nature conservation perspective.

\section{Acknowledgements}

This scientific work was funded by science finance in the years 2010-2013 as a research project (grant No. N N305 384938). Michele Simmons improved the language of the paper.

\section{Conflict of Interest}

The authors declare no conflict of interest.

\section{References}

1. PRACH K., LENCOVÁ K., ̌̌EHOUNKOVÁ K., DVOŘÁKOVÁ H., JíROVÁ A., KONVALINKOVÁ P.,
MUDRÁK O., NOVÁK J., TRNKOVÁ R. Spontaneous vegetation succession at different central European mining sites: a comparison across seres. Environ. Sci. Poll. Res. 20 (11), 7680, 2013.

2. PRACH K., TICHÝ L., VITOVCOVA K., ŘEHOUNKOVÁ K. Participation of the Czech flora in succession at disturbed sites: quantifying species' colonization ability. Preslia. 89, 87, 2017.

3. PRACH K., ŘEHOUNKOVÁ K., LENCOVÁ K., JÍROVÁ A., KONVALINKOVÁ P., MUDRÁK O., ŠTUDENT V., VANĚČEK Z., TICHÝ L., PETŘÍK P., ŠMILAUER P., PYŠEK P. Vegetation succession in restoration of disturbed sites in Central Europe: the direction of succession and species richness across 19 seres. App. Veg. Sci. 17 (2), 193, 2014.

4. PRACH K., KAREŠOVÁ P., JÍROVÁ A., DVOŘÁKOVÁ H., KONVALINKOVÁ P., ŘEHOUNKOVÁ K. Do not neglect surroundings in restoration of disturbed sites. Restoration Ecol. 23 (3), 310, 2015.

5. RAHMONOV O., SZYMCZYK A. Relations between vegetation and soil $\mathrm{n}$ initial succession phases in post-sand excavations. Ekológia (Bratislava). 29 (4), 412, 2010.

6. HORÁČKOVÁ M., ŘEHOUNKOVÁ K., PRACH $\mathrm{K}$. Are seed and dispersal characteristics of plants capable of predicting colonization of post-mining sites? Environmental Sci. Poll. Res. 23 (14), 13617, 2016.

7. RZĘTAŁA M., JAGUŚ A. New lake district in Europe: origin and hydrochemical characteristics. Water Environ. J. 26, (1), 108, 2012.

8. MOLENDA T., BŁOŃSKA A., CHMURA D. Hydrochemical diversity of selected anthropogenic wetlands developed in disused sandpits. 13th International Multidisciplinary Scientific. Conference Proceedings 1, 547, 2013.

9. KOMPAŁA-BĄBA A., BĄBA W. The spontaneous succession in a sand-pit - the role of life history traits and species habitat preferences. Pol. J. Ecol. 61 (1), 13, 2013.

10. KÖNIG P. Plant diversity and dynamics in chalk quarries on the islands of Rügen and Wolin (Western Pomerania/ Germany and Poland). Biodivers. Res. Conserv. 47 (1), 23, 2017. 
11. WILAND-SZYMAŃSKA J., BUCZKOWSKA K., DRAPIKOWSKA M., MAŚLAK M., BĄCZKIEWICZ A., CZYLOK A. Genetic structure and barcode identification of an endangered orchid species, Liparis loeselii, in Poland. Systematics and Biodiversity. 14 (4), 345, 2016.

12. CZYLOK A., RAHMONOV O., SZYMCZYK A. Biological diversity in the area of quarries after sand exploitation in the eastern part of Silesian Upland. Teka Kom. Ochr. Kszt. Środ. Przyr. OL PAN 5A, 15, 2008.

13. BZDON G. Post-exploitation excavations as supplementary habitats for protected and rare vascular plant species. In: MIREK Z., NIKIEL A. (eds). Rare, relicts and endangered plants and fungi in Poland, W. Szafer Institute of Botany Polish Academy of Sciences, 137, Kraków, 2009.

14. CZYLOK A., SZYMCZYK A., Sand quarries as biotopes of rare and critically endangered plant species. In: MIREK Z., NIKIEL A. (eds). Rare, relicts and endangered plants and fungi in Poland, W. Szafer Institute of Botany Polish Academy of Sciences, Kraków, 187, 2009.

15. STEBEL A., BŁOŃSKA A. Moerckia hibernica (Marchantiophyta) in anthropogenic habitats in southern Poland. Herzogia. 25 (1), 113, 2010.

16. STEBEL A., BŁOŃSKA A. Habitat conditions of occurrence of Ptychoverpa bohemica (Krombh.) Boud. (Morchellaceae) in anthropogenic habitats in southern Poland. Acta Musei Siles. Scientiae Naturales 65 (2), 135, 2016.

17. DULIAS R., Denudacja antropogeniczna na obszarach górniczych na przykładzie Górnośląskiego Zagłębia Węglowego. Wydawnictwo Uniwersytetu Śląskiego, Katowice, 2013 [In Polish].

18. GUTRY-KORYCKA M., WERNER-WIECCKOWSKA H. (eds). Przewodnik do hydrograficznych badań terenowych. Wydawnictwo Naukowe PWN, 1989 [In Polish].

19. MOLENDA T. Impact of saline mine water: development of a meromictic reservoir in Poland. Mine Water Environ., 33, 327, 2014.

20. ELLENBERG H., LEUSCHNER C. Vegetation Mitteleuropas mit den Alpen: in ökologischer, dynamischer und historischer Sicht. Vol. 8104. Utb, 2010.

21. MATUSZKIEWICZ W. Przewodnik do oznaczania zbiorowisk roślinnych Polski. Vademecum Geobotanicum 3, Wydawnictwo Naukowe PWN, Warszawa, 2018 [In Polish].

22. Regulation of the Minister of the Environment of 9 October 2014 on the protection of plant species. Dz.U. 2014 poz. 1409 [In Polish].

23. KAŹMIERCZAKOWA R., BLOCH-ORŁOWSKA J., CELKA Z., CWENER A., DAJDOK Z., MICHALSKA-
HEJDUK D., PAWLIKOWSKI P., SZCZEŚSIAK E., ZIARNEK K. Polska czerwona lista paprotników i roślin kwiatowych. Polish red list ofpteridophytes and flowering plants. Kraków: Instytut Ochrony Przyrody Polskiej Akademii Nauk, 2016.

24. Euro+Med PlantBase - the information resource for EuroMediterranean 464 plant diversity. URL http://ww2.bgbm. org/EuroPlusMed/ (accessed 12.29.17).

25. DULIAS R. The Impact of Mining on the Landscape: A Study of the Upper Silesian Coal Basin in Poland. Environmental Science and Engineering, Springer, Switzerland, 209, 2016.

26. JABŁOŃSKA-CZAPLA M., NOCOŃ K., SZOPA S., ŁYKO A. Impact of the $\mathrm{Pb}$ and $\mathrm{Zn}$ ore mining industry on the pollution of the Biała Przemsza River, Poland. Environ. Monit. Assess. 188 (5), 262, 2016.

27. NOCOŃ W., NOCOŃ K., BARBUSIŃSKI K., KERNERT J. The influence of zinc-lead ore mining industry on the level of the Biała Przemsza bottom sediments contamination. ACEE. 5 (1), 65,2012.

28. MOTYKA J., d'OBRYN K., JUŚKO K., WÓJCIK T. Chemistry of water from the inflows to the "Franciszek" dipheading in the "Pomorzany" $\mathrm{Zn}-\mathrm{Pb}$ mine in the Olkusz Area (SW Poland).J. Sustainable Mining 16, 139, 2017.

29. MOLENDA T. Natural and anthropogenic conditions of physical and chemical water changes in post - mining aquatic areas of Upper Silesian region and its neighboring area. Wydawnictwo Uniwersytetu Śląskiego, Katowice, 2011.

30. NOWAK A., MAŚLAK M., NOBIS M., NOWAK S., KOJS P., SMIEJA A. Is the riparian habitat creation an effective measure of plant conservation within the urbanized area?. Ecol. Engineering. 83, 125, 2015.

31. DUVAL T.P., WADDINGTON J.M. Effect of hydrogeomorphic setting on calcareous fen hydrology. Hydrological Processes. 32 (11), 1695, 2018.

32. JABŁOŃSKA E., PAWLIKOWSKI P., JARZOMBKOWSKI F., CHOROMAŃSKI F.J., OKRUSZKO T., KŁOSOWSKI S. Importance of water level dynamics for vegetation patterns in a natural percolation mire (Rospuda fen, NE Poland). Hydrobiologia 674, 105, 2011.

33. KUSCU I.S.K., CETIN M., YIGIT N., SAVACI G., SEVIK H. Relationship between enzyme activity (Ureasecatalase) and nutrient element in soil use. Pol. J. Environ. Stud. 27 (5), 2107, 2018.

34. HORSÁKOVÁ V., HÁJEK M., HÁJKOVÁ P., DÍTĚ D., HORSÁK M. Principal factors controlling the species richness of European fens differ between habitat specialists and matrix-derived species. Divers. Distrib. 24 (6), 742, 2018. 
Table S1. List of vascular plant species found in Szczakowa swamp.

\begin{tabular}{|c|c|}
\hline Achillea millefolium & Juncus tenuis \\
\hline Agrostis stolonifera & Leontodon hispidus \\
\hline Alnus glutinosa & Linum catharticum \\
\hline Alnus incana & Liparis loeselii \\
\hline Angelica sylvestris & Lotus uliginosus \\
\hline Betula pendula & Lycopus europaeus \\
\hline Betula pubescens & Lysimachia thyrsiflora \\
\hline Briza media & Lysimachia vulgaris \\
\hline Carex acuta & Lythrum salicarnia \\
\hline Carex davalliana & Majanthemum bifolium \\
\hline Carex dioica & Malaxis monophyllos \\
\hline Carex echinata & Mantha aquatica \\
\hline Carex flacca & Menthaarvensis \\
\hline Carex flava & Molinia caerulea \\
\hline Carex nigra & Myosotis palustris \\
\hline Carex panicea & Parnassia palustris \\
\hline Carex rostrata & Pedicularis palustris \\
\hline Carex vesicaria & Peucedanum palustre \\
\hline Carex viridula & Phragmites australis \\
\hline Cirsium oleraceum & Picea excelsa \\
\hline Cirsium palustre & Pinus sylvestris \\
\hline Cirsiumm rivulare & Potentilla anserina \\
\hline Convallaria majlais & Potentilla erecta \\
\hline
\end{tabular}

\begin{tabular}{|c|c|}
\hline Dactylorhiza incarnata & Prunella vulgaris \\
\hline Dactylorhiza majalis & Ranunculus acris \\
\hline Deschampsia caespitosa & Salix alba \\
\hline Eleocharis pauciflora & Salix pendandra \\
\hline Eloecharis uniglumis & Salix rosmarinifolia \\
\hline Epipactis palustris & Sanguisorba officinalis \\
\hline Equisetum fluviatile & Scirpus sylvaticus \\
\hline Equisetum palustre & Scutellaria gallericulata \\
\hline Equisetum variegatum & Sparganium erectum \\
\hline Eriophorum angustifolium & Succisia pratensis \\
\hline Eriophorum latifoium & Taraxacum officinale \\
\hline Euparorium cannabiunum & Tofieldia calyculata \\
\hline Festuca rubra & Trifoliuim medium \\
\hline Filipendula ulmaria & Triglochin palustre \\
\hline Frangula alnus & Tusillago farfara \\
\hline Galium palustre & Utricularia \\
\hline Galium uliginosum & Valeriana officinalis \\
\hline Gentiana pneumonanthe & Valeriana simplicifolia \\
\hline Gymnadenia conopsea & Vicia cracca \\
\hline Hypericum tetrapterum & Vicia tenuifolia \\
\hline Juncus alpino-articulatus & Schoenoplecutus lacustris \\
\hline Juncus atriculatus & Centhurium erythrea ssp. \\
\hline erythrea \\
\hline
\end{tabular}

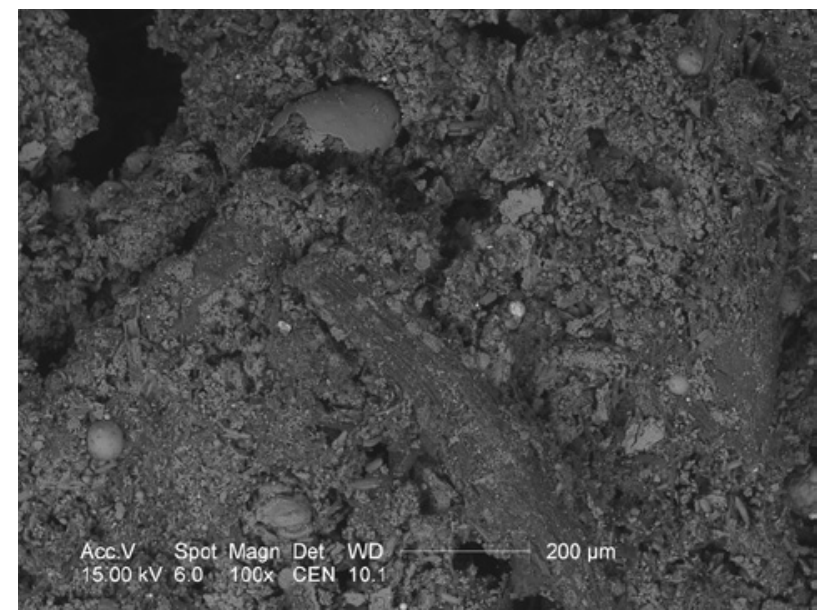

Fig. S1. A SEM photograph of the particles of calcium carbonate $\mathrm{CaCO}_{3}$ (spherical piece in the upper left corner) in the material that was collected from the rhizosphere of Liparis loeselii in swamp Szczakowa. 